\title{
Sistem Informasi Lalu Lintas Ternak (Studi Kasus Dinas Pertanian dan Peternakan Kayong Utara) \\ Sania $^{\# 1}$, Heri Priyanto ${ }^{\# 2}$, Yulianti ${ }^{\# 3}$ \\ ${ }^{\text {\#Program Studi Informatika Universitas Tanjungpura }}$ \\ Jl. Prof. Dr. H. Hadari Nawawi, Pontianak 78124 \\ ${ }^{1}$ sania1995160gmail.com \\ 2heripriyantodinformatika.untan.ac.id \\ ${ }^{3}$ yuliantidinformatika.untan.ac.id
}

\begin{abstract}
Abstrak-Unit Pelaksana Teknis Daerah (UPTD) Balai Pengujian dan Penyidikan Penyakit Hewan merupakan bagian dari Dinas Peternakan Kayong Utara. Pada Balai Pengujian dan Penyidikan Penyakit Hewan sistem informasi sangat berpengaruh dalam mendukung peningkatan pembangunan peternakan dan pelayanan veteriner (mengenai penyakit hewan) nasional. Pelaksaan pelayanan pengawasan veteriner perlu dilakukan identifikasi dan pengawasan terhadap lalulintas ternak. Peraturan Bupati Pasal 1 No. 16 Tahun 2018, lalu lintas ternak adalah keluarmasuk antar daerah/pulau, mutasi dan keluar-masuk daerah produk peternakan. Pelaksanaan pengawasan lalu lintas ternak antar kabupaten dilakukan di Pos Pemeriksaan Ternak atau PPT (check point) oleh Dinas yang membidangi fungsi peternakan dan kesehatan hewan di Kabupaten/Kota. Tujuan dari penelitian adalah membangun sebuah sistem informasi yang dapat membantu kepala bidang peternakan dan kesehatan hewan dalam membuat kebijakan, evaluasi dan administrasi peternakan dan kesehatan hewan. Kepala bidang peternakan dan kesehatan hewan memiliki tugas dan fungsi melakukan kontrol dan koordinasi terhadap lalu lintas ternak, meliputi jumlah dan kondisi hewan ternak pada Dinas Pertanian dan Peternakan Kayong Utara. Metodologi penelitian yang dilakukan yaitu studi literatur, analisis kebutuhan, pengumpulan data, perancangan, implementasi, pengujian dan penarikan kesimpulan. Model pengembangan sistem menggunakan konsep System Development Life Cycle (SDLC). Pengujian sistem dilakukan dengan pengujian black box dan aspek usability. Hasil pengujian black box adalah sistem dapat bekerja dengan baik dan hasil dari pengujian usability dengan 3 orang responden dari 8 pertanyaan, 6 diantaranya memiliki nilai diatas $80 \%$. Sehingga disimpulkan sistem dapat membantu kepala bidang peternakan dan kesehatan hewan dalam membuat kebijakan, evaluasi dan administrasi peternakan dan kesehatan hewan.
\end{abstract}

Kata kunci- Lalu Lintas Ternak, PPT (check point), veteriner, SDLC, Sistem Informasi.

\section{PENDAHULUAN}

Pada masa sekarang ini suatu pekerjaan dituntut untuk lebih professional dan efisien. Seiring dengan hal tersebut maka harus dilakukan perubahan kearah perbaikan disegala bidang. Hal ini diakibatkan karena terus berkembang pesatnya ilmu pengetahuan. Salah satunya adalah di bidang teknologi dan informasi. Perkembangan pengetahuan teknologi dan informasi sangat dirasakan dengan diciptakannya alat elektronik yang disebut dengan komputer. Komputer didefinisikan sebagai sebuah mesin penghitung elektronik yang cepat dapat menerima informasi input digital, memprosesnya sesuai dengan suatu program yang tersimpan di memorinya (stored program) dan menghasilkan output informasi [1]

Unit Pelaksana Teknis Daerah (UPTD) Balai Pengujian dan Penyidikan Penyakit Hewan merupakan bagian dari Dinas Peternakan Kayong Utara. Pada Balai Pengujian dan Penyidikan Penyakit Hewan sistem informasi sangat berpengaruh dalam mendukung peningkatan pembangunan peternakan dan pelayanan veteriner (mengenai penyakit hewan) nasional. Dalam pelaksaan pelayanan pengawasan veteriner (mengenai penyakit hewan) perlu dilakukan identifikasi dan pengawasan terhadap lalu lintas ternak. Lalu lintas ternak adalah keluar-masuk antar daerah/pulau, mutasi dan keluarmasuk daerah produk peternakan [2]. Pelaksanaan pengawasan lalu lintas ternak antar kabupaten dilakukan di Pos Pemeriksaan Ternak atau PPT (check point) oleh Dinas yang membidangi fungsi peternakan dan kesehatan hewan di Kabupaten/Kota. Pelayan Izin Pengeluaran Ternak adalah segala kegiatan pelayanan izin pengeluaran ternak yang akan di kirim atau dikeluarkan dari Kabupaten Kayong Utara atas milik perusahaan atau masyarakat pengirim ternak [2]. Kemudian dari proses (check point) petugas yang berwenang akan menerbitkan (SKKH) Surat Keterangan Kesehatan Hewan sesuai kondisi ternak, sehingga di harapkan mampu mencegah masuknya penyakit hewan menular straregis (PHMS) dari 
Provinsi lain ke Provinsi Kalimantan Barat. Serta mencegah terjadinya berbagai bentuk penyimpangan/pemalsuan yang menyangkut keamanan mutu hewan ternak.

Proses pelaksanaan pengawasan lalu lintas ternak Kabupaten Kayong Utara saat masih dalam tahap peningkatan mutu pelayanan, yang mana saat ini proses pelayanan yang di lalukan pada pos pemeriksaan ternak atau PPT (check point) masih menggunakan cara yang konvensional. Petugas pemeriksaan ternak atau PPT (check point) mendata dengan buku besar dan akan di rekap kembali untuk bahan pelaporan, sehingga menjadikan proses pekerjaan ini memakan waktu lama.

Berdasarkan uraian diatas, maka diperlukan suatu sistem informasi yang dapat membantu dalam pelaksaan pelayan pengawasan veteriner (mengenai penyakit hewan) pada proses lalulintas ternak, yang dapat mengelola data lalu lintas ternak, menyiapkan laporan lalu lintas ternak, menerbitkan Surat Keterangan Kesehatan Hewan, memberikan informasi populasi/pertumbuhan ternak serta informasi stok hewan potong dan non potong.

\section{StUdi LiterAtUR}

\section{A. Penelitian Terkait}

Beberapa peneliti terdahulu telah melakukan penelitian tentang aplikasi pendataan berbasis web, salah satunya adalah penelitian berjudul "Rancang Bangun Sistem Informasi Pengolahan Data Ternak Di Perusahaan Dagang Perusahaan Pengembangan Usaha Ternak Indonesia (PD. PPUTI)" [3]. Tujuan penelitian tersebut adalah untuk merancang dan membuat suatu model sistem informasi pengolahan data ternak, sehingga dapat menghasilkan laporan yang tepat, cepat, dan akurat. Metode pengumpulan data yang digunakan adalah metode kepustakaan dan lapangan. Hasil yang telah dicapai adalah dengan adanya aplikasi pengolahan data ternak, dapat mempermudah pengolahan data transaksi dan persediaan produk maupun barang serta mempercepat dalam pembuatan laporan transaksi dan stok.

Kemudian penelitian berjudul "Perancangan Sistem Informasi Pendataan Ternak menggunakan PHP dan MySQL"[4] penelitian ini menghasilkan sebuah aplikasi yang dapat mengintegrasikan data yang ada di kecamatan dan kabupaten, sehingga konsistensi data dapat terjamin serta mempercepat proses pendistribusian data, pencarian data, dan mempermudah proses pembuatan laporan peternakan yang mampu memberi sajian yang lengkap. Aplikasi ini dibangun dengan php dan MySQL.

Kemudian penelitian yang berjudul "Sistem Informasi Berbasis Web Pada Dinas Peternakan dan Perikanan Kabupaten Tanah Datar'[5]. Adapun tujuan dari penulisan ini adalah merancang sistem informasi berbasis web berdasarkan penerima bantuan yang disalurkan oleh Dinas Peternakan Dan Perikanan Kabupaten Tanah Datar. Sehingga peng-input-kan data, pengeditan data serta penyimpanan data bisa berjalan secara efektif dan efisien dan pembuatan laporan akan lebih cepat pengolahannya.
Berdasarkan beberapa penelitian tersebut, penelitian yang akan dilalukan berikutnya yaitu berfokus pada Sistem Informasi Lalu Lintas Ternak pada Dinas Pertanian dan Peternakan Kayong Utara yang berbasis Website. Tujuan dari penelitian ini adalah menghasilkan Sistem Informasi Lalu Lintas Ternak yang mengelola data hewan ternak yang masuk dan keluar sehingga memudahkan dalam proses pencarian data lalu lintas ternak, populasi ternak dan stok hewan potong dan non potong pada Dinas Pertanian dan Peternakan Kayong Utara dan dapat membantu kepala bidang peternakan dan kesehatan hewan dalam membuat kebijakan, evaluasi dan administrasi peternakan dan kesehatan hewan. Kepala bidang peternakan dan kesehatan hewan memiliki tugas dan fungsi melakukan kontrol dan koordinasi terhadap lalu lintas ternak, meliputi jumlah dan kondisi hewan ternak pada Dinas Pertanian dan Peternakan Kayong Utara.

\section{B. Definisi Sistem}

Ada beberapa pengertian tentang definisi sistem yang sedang berjalan oleh beberapa ahli, yaitu: Sistem adalah sekumpulan dari elemen-elemen yang berinteraksi untuk mencapai suatu tujuan tertentu [6]. Sistem adalah sekumpulan atau group dari subsistem/bagian/komponen apapun baik fisik yang saling berhubungan satu sama lain dan bekerja sama secara harmonis untuk mencapai suatu tujuan tertentu [7].

Berdasarkan pengertian dari beberapa para ahli, bisa disimpulkan bahwa definisi sistem adalah sekumpulan dari beberapa elemen tertentu yang saling berhubungan/berinteraksi satu sama lain sehingga membentruk suatu kesatuan untuk mencapai tujuan tertentu.

\section{Definisi Informasi}

Ada bebrapa pengertian informasi menurut para ahli, diantaranya: Informasi adalah data yang telah diolah menjadi sebuah bentuk yang berarti bagi penerimanya dan bermanfaat bagi pengambilan keputusan saat ini atau mendatang [8]. Informasi adalah data yang diolah sehingga dapat dijadikan dasar untuk mengambil keputusan yang tepat [9].

Berdasarkan pengertian para ahli di atas, informasi dapat diartikan sebagai bebrapa data telah diolah menjadi suatu bentuk yang penting sehingga dapat memberikan nilai yang bermanfaat bagi si penerima.

\section{Definisi Sistem Informasi}

Sistem informasi adalah suatu kombinasi terartur apapun dari people (orang), hardware (perangkat keras), software (piranti lunak), computer networks and data communications (jaringan komunikasi), dan database (basis data) yang mengumpulkan, mengubah dan menyebarkan informasi di dalam suatu bentuk organisasi [10].

Sistem informasi adalah sistem di dalam suatu organisasi yang mempertemukan kebutuhan pengolahan 
transaksi harian, membantu dan mendukung kegiatan operasi, bersifat manajerial dari suatu organisasi dan membantu mempermudah penyediaan laporan yang diperlukan [11].

\section{E. System Development Life Cycle (SDLC)}

SDLC merupakan pendekatan bertahap atau fase untuk melakukan analisa dan membangun rancangan sistem dengan menggunakan siklus yang spesifik terhadap kegiatan pengguna [12]. SDLC juga merupakan pola yang diambil untuk mengembangkan sistem perangkat lunak, yang terdiri dari tahapan: analisa (analysis), desain (design), implementasi (implementation), dan uji coba (testing). Konsep SDLC mendasari berbagai jenis metodologi pengembangan perangkat lunak yang membentuk suatu kerangka kerja untuk perencanaan dan pengendalian pembuatan sistem informasi, yaitu proses pengembangan perangkat lunak.

SDLC merupakan salah satu model dalam perancangan piranti lunak oleh pengguna melalui beberapa tahapan agar mendapatkan hasil output yang sesuai [13].

\section{F. Waterfall}

Terdapat beberapa metodologi SDLC yang biasa digunakan dalam membangun sebuah sistem, salah satunya adalah model waterfall. Waterfall merupakan model yang bersifat sistematis dan termasuk dalam model klasik, nama lainnya adalah Linear Sequential Model. Tahapan-tahapan model waterfall dapat dilihat pada Gambar 1.

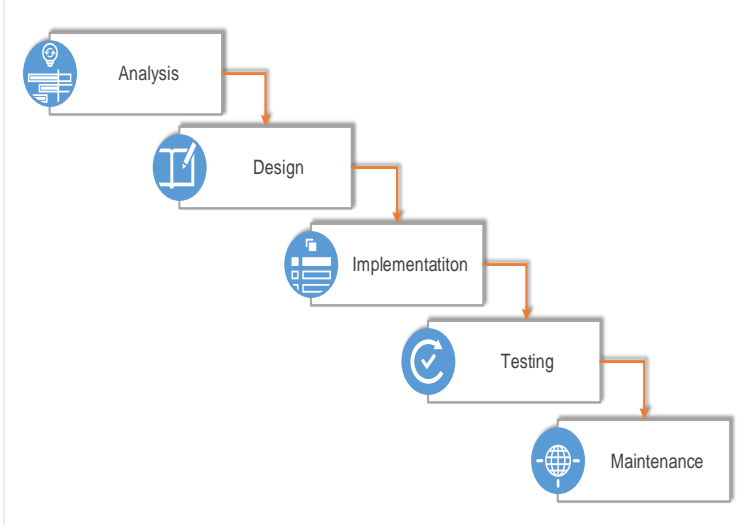

Gambar 1. Linear sequential mode

Penjelasan tahapan-tahapan waterfall tersebut yaitu:

1) Analysis (Analisis): Fase ini merupakan proses analisa terhadap sistem yang sedang berjalan dengan tujuan untuk mendapatkan jawaban mengenai pengguna sistem, cara kerja sistem dan waktu penggunaan sistem, sehingga kebutuhan yang diperlukan untuk sistem baru akan didapatkan.
2) Design (Perancangan): Perancangan merupakan proses penentuan cara kerja sistem dalam hal perancangan antarmuka, database, dan perancangan alur program. Perancangan diperlukan untuk mengGambarkan sistem baru dengan tujuan memenuhi kebutuhan pengguna.

3) Implementation (Implementasi): Tahapan implementasi yaitu tahap rancangan sistem yang dibentuk menjadi suatu kode program untuk pembuatan sistem.

4) Testing (Pengujian): Pengujian program dilakukan untuk mengetahui kesesuaian sistem berjalan sesuai prosedur atau tidak dan memastikan sistem terhindar dari error yang terjadi. Testing juga dilakukan untuk memastikan kevalidan dalam proses input sehingga dapat menghasilkan output yang sesuai.

5) Maintenance (Pemeliharaan): Fase ini yaitu pemeliharaan dan pengembangan sistem yang berguna untuk melihat kemampuannya, mengecek jika masih ada ditemukan error atau ada penambahan fitur-fitur yang belum ada pada sistem tersebut. Pengembangan diperlukan ketika adanya perubahan dari pengguna seperti ketika ada pergantian sistem operasi, atau perangkat lainnya.

\section{G. Lalu Lintas Ternak}

Lalu lintas ternak adalah keluar-masuk antar daerah/pulau, mutasi dan keluar-masuk daerah produk peternakan [2].

\section{H. Pelayan Izin Pengeluaran Ternak}

Pelayan Izin Pengeluaran Ternak adalah segala kegiatan pelayanan izin pengeluaran ternak yang akan dikirim atau dikeluarkan dari Kabupaten Kayong Utara atas milik perusahaan atau masyarakat pengirim ternak [2]

\section{Surat Keterangan Pengeluaran Ternak (SKKH)}

Surat Keterangan Pengeluaran Ternak (SKKH) adalah surat keterangan yang diterbitkan oleh Dinas Pertanian dan Peternakan dan ditandatangani oleh pejabat yang berwenang setelah melalui proses pemeriksaan kesehatan ternak [2]

\section{J. Pengujian Perangkat Lunak}

Pengujian perangkat lunak merupakan suatu teknik yang digunakan menguji apakah sebuah perangkat lunak yang dihasilkan telah sesuai dengan yang diharapkan atau belum. Pengujian adalah proses eksekusi suatu program untuk menemukan kesalahan sebelum digunakan oleh pengguna akhir (end-user) [14].

\section{K. Pengujian Aspek Usability}

Karakteristik ini mempresentasikan sejauh mana suatu produk atau sistem dapat digunakan oleh pengguna tertentu untuk mencapai tujuan tertentu dengan efektif, efisien dan kepuasan dalam konteks tertentu. Usability adalah atribut kualitas yang menilai betapa mudahnya user interface dari perangkat yang digunakan [15]. 
Pengujian aspek usability adalah bagian besar dari usaha untuk meningkatkan profitabilitas produk. Ada banyak aspek untuk melakukannya, yang pada akhirnya juga sangat menguntungkan pengguna: keputusan desain diinformasikan oleh data yang dikumpulkan dari perwakilan pengguna untuk mengekspos masalah desain sehingga mereka dapat diperbaiki, sehingga meminimalkan atau menghilangkan rasa frustrasi bagi pengguna [16].

Analisis pengujian aspek usability menggunakan skala likert. Skala likert digunakan untuk mengukur sikap, pendapat, dan persepsi seseorang atau sekelompok orang tentang fenomena sosial. Jawaban setiap item instrumen yang menggunakan skala likert mempunyai gradasi dari sangat setuju sampai sangat tidak setuju [17].

Untuk mencari interval nilai persentase dari masingmasing jawaban dengan metode mencari interval nilai persentase Likert sebagai berikut:

\section{Keterangan:}

$$
\mathbf{I}=(\mathbf{1 0 0 \%}) /(\text { Jumlah Skor Likert })
$$

\section{$\mathrm{I}=$ Interval nilai persentase Likert}

Jumlah skor likert yang dipakai ada 5, yaitu 5, 4, 3, 2, dan 1. Maka perhitungan jarak persentase adalah $100 / 5=20$. 20 adalah interval nilai persentase.

Perhitungan untuk mencari nilai total adalah dengan cara mengalikan setiap poin instrumen dengan poin yang telah ditentukan sebelumnya kemudian menjumlahkan hasilnya.

Nilai Total $=1 x($ STB $)+2 x($ TB $)+3 x(C B)+4 x(B)+$ 5x(SB)

Perhitungan untuk mencari nilai persentase yaitu dengan cara membagi Nilai Total dengan hasil perkalian antara poin tertinggi jawaban dengan banyaknya responden kemudian dikalikan $100 \%$

\section{$\mathbf{P}=($ Nilai Total $) /($ Skor Ideal $) \times 100 \%$}

Keterangan:

$\mathrm{P} \quad=\quad$ Nilai persentase yang dicari. Nilai Total = Jumlah dari poin instrumen dikalikan dengan poin jawaban.

Skor ideal = Poin tertinggi jawaban dikalikan dengan jumlah responden.

Perhitungan mencari total persentase keseluruhan guna mendapatkan tingkat persetujuan, rumusnya adalah dengan menjumlahkan semua nilai persentase lalu membaginya dengan jumlah total pertanyaan.

\section{Total Persentase $=\frac{\sum P}{\sum \text { pertanyaan }}$}

Dengan perhitungan persentase menggunakan rumus di atas akan diketahui apakah penelitian yang dilakukan oleh penulis sudah mampu untuk memenuhi tujuan dari penelitian yang dilakukan.

\section{Pengujian Black Box}

Metode pengujian black box merupakan pengujian yang dipilih berdasarkan spesifikasi masalah tanpa memperhatikan detail internal dari program, pengujian dilakukan untuk memeriksa apakah program dapat berjalan dengan benar [18].

Blackbox testing berusaha untuk menemukan kesalahan dalam kategori sebagai berikut:

1. Fungsi-fungsi yang tidak benar atau fungsi yang hilang

2. Kesalahan antarmuka (interface)

3. Kesalahan dalam struktur data atau akses database eksternal

4. Kesalahan perilaku (behavior) atau kesalahan kinerja 5. Inisialisasi dan pemutusan kesalahan.

Pengujian black box terdapat beberapa teknik uji coba, yaitu Equivalence Partitioning, Comparison Testing, Sample Testing, Robustness Testing, Behavior Testing, Performance Testing, Requirement Testing, Cause-Effect Relationship Testing, Boundary Value Analysis, dan Edurance Testing.

Teknik uji coba pada black box yang akan digunakan adalah Robustness Testing yang merupakan pengujian dengan data input dipilih di luar spesifikasi yang telah didefinisikan untuk membuktikan bahwa tidak ada kesalahan walaupun masukannya tidak valid, teknik ini dilakukan pada uji coba proses input data.

\section{Metodologi Penelitian}

\section{A. Metodologi Penelitian}

Metodologi penelitian merupakan suatu perencanaan penelitian yang akan dilakukan secara sistematis dan ilmiah. Pada penelitian ini, dibagngun dengan mendesain perencanaan penelitian sehingga mudah untuk dilakukan. Metodologi penelitian tersebut diilustrasikan pada Gambar 2.

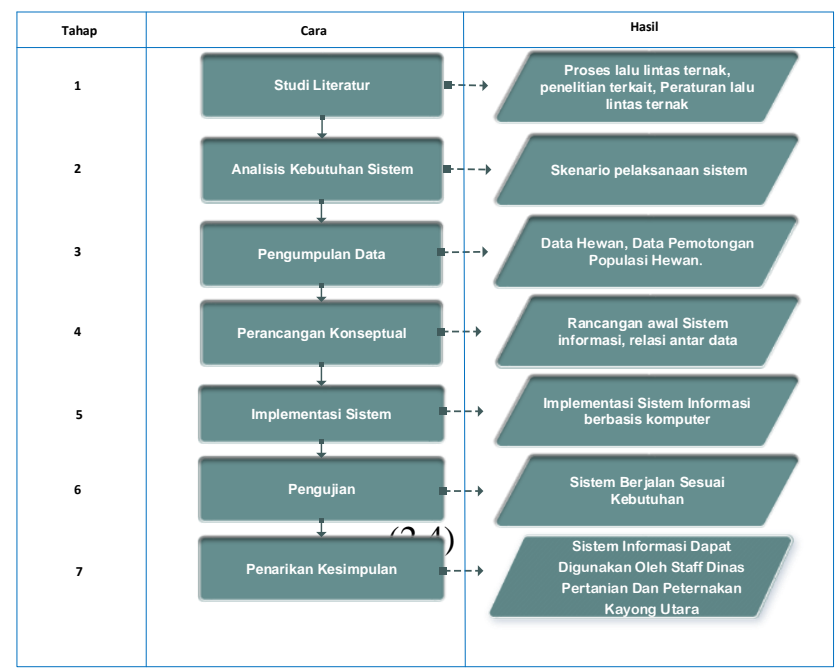

Gambar 2. Diagram alir penelitian

\section{B. Analisis Sistem Yang Sedang Berjalan}

Sistem yang berjalan pada Dinas Pertanian dan Peternakan Kayong Utara masih dilakukan secara konvensional atau belum terkomputerisasi dengan baik. 
Adapun kegiatan pelaksanaan proses pendataan lalu lintas ternak yaitu dapat dilihat pada Gambar 3 .

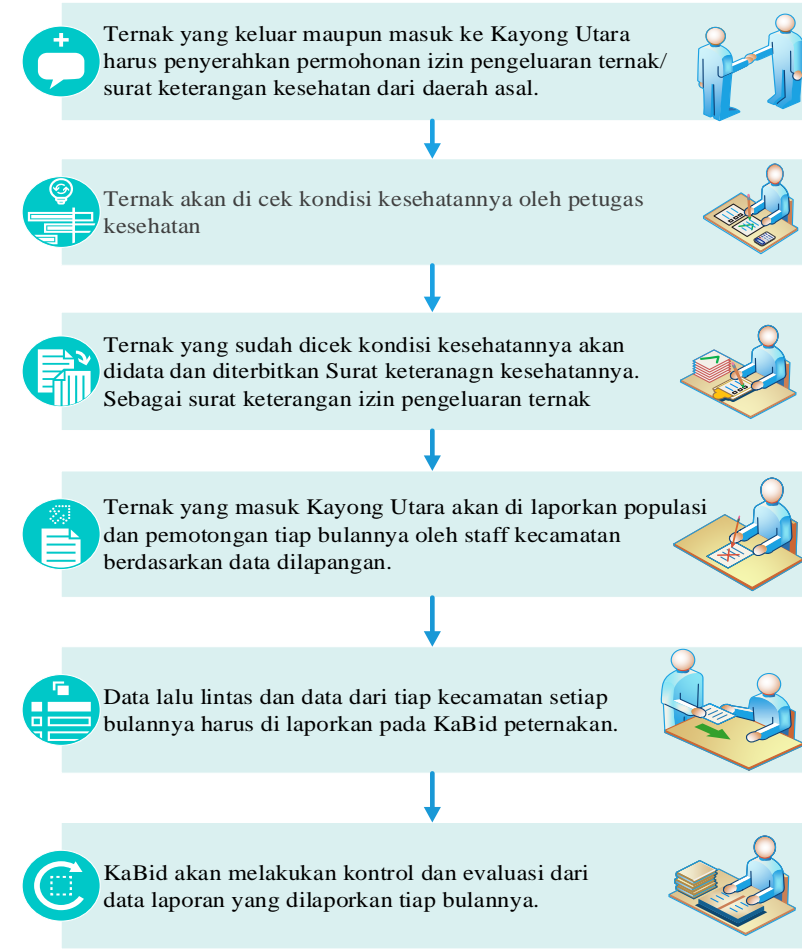

Gambar. 3 sistem yang sedang berjalan

\section{Data Penelitian}

Data penelitian berupa data dari Dinas Pertanian dan Peternakan Kayong Utara. Adapun data yang diperlukan ialah data ternak, proses lalu lintas ternak, data pemotongan hewan, data populasi, data jenis ternak, dan pelaksanaan lalu lintas ternak sesuai dengan peraturan Bupati Kayong Utara.

Semua data yang diperoleh di dapatkan dengan cara:

1) Studi literatur: mencari jurnal terkait yang mendukung kebutuhan pembuatan sistem, mempelajari peraturan perundang-undangan Bupati Kayong Utara tentang Lalu Lintas Ternak dan atau Bahan Asal Ternak

2) Wawancara: Melakukan tanya jawab dengan KaBid Dinas Peternakan mengenai proses pelaksanaan lalu lintas ternak yang ada di Dinas Pertanian dan Peternakan Kayong Utara, yang akan dijadikan acuan dalam sistem yang akan dibangun. Kuisioner yang akan diberikan kepada subjek penelitian berupa pertanyaan tentang sistem informasi yang akan dibuat. Hasil dari tanggapan pengguna sistem informasi akan menjadi hasil dari penelitian berhasil atau tidak.

\section{Perancangan Arsitektur Sistem}

Arsitektur sistem merupakan cara yang digunakan untuk mengGambarkan sistem secara umum, Gambaran arsitektur tersebut dibangun berdasarkan informasi yang didapatkan dari wawancara dan sistem yang berjalan sekarang ini. Komponen sistem terdiri dari data dan informasi atau proses, seperti pada Gambar 4, sistem informasi yang akan dibangun ini berbasis web, yang dapat diakses oleh staff admin, staff kecamatan, staff lantas dan pimpinan. Staff admin harus login terlebih dahulu agar dapat mengaksses sistem informasi dan mengolah data lalu lintas ternak mulai dari data hewan ternak, data pemilik ternak, penerima ternak, jumlah ternak, kondisi ternak, jenis ternak dan manajemen data pengguna, staff kecamatan harus login terlebih dahulu agar dapat mengolah data populasi ternak dan pemotongan ternak dan melihat informasi hewan ternak. Staff lantas harus login terlebih dahulu untuk mengakses halaman sistem informasi dan mengolah data lalu lintas ternak. Pimpinan harus login terlebih dahulu agar dapat melihat informasi dan data yang ada pada pada sistem. Semua data yang telah diproses pada sistem nanti akan menjadi acuan laporan.

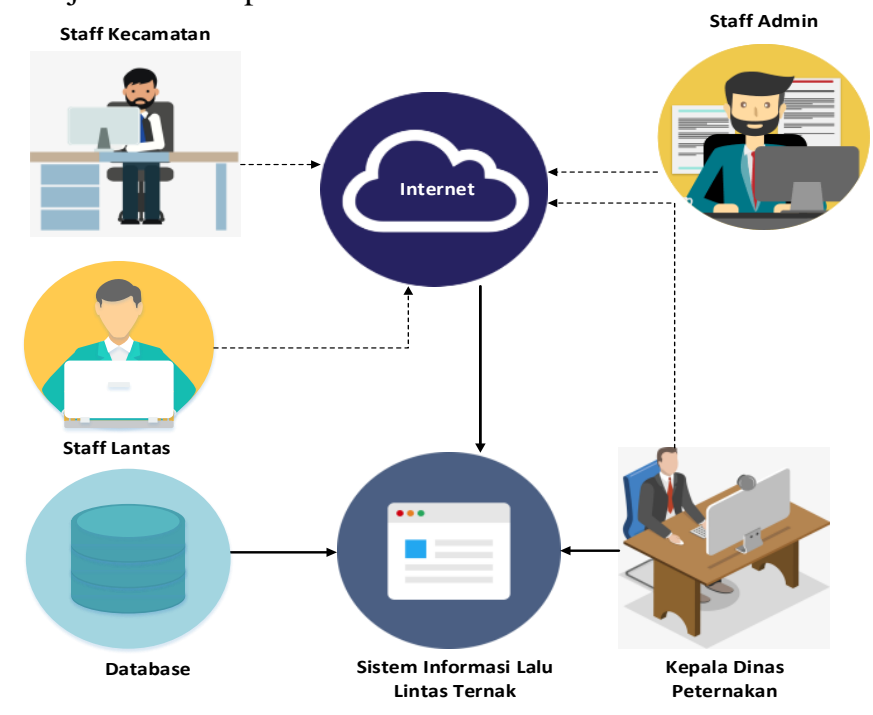

Gambar 4. Arsitektur sistem informasi lalu lintas ternak

E. Diagram Konteks

Diagram Konteks terdiri dari suatu proses dan mengGambarkan ruang lingkup suatu sistem. Diagram konteks ini merupakan bagian tingkatan tertinggi dari DFD yang mengGambarkan seluruh input ke suatu sistem atau output dari sistem dan hanya memuat satu proses. Diagram konteks Siatem Informasi Lalu Lintas Ternak terdiri dari 4 entitas yaitu staff admin, staff lantas, staff kecamatan, dan pimpinan/kepala Dinas Pertanian dan Peternakan Kayong Utara. Diagram konteks dari Sistem Infirmasi Lalu Lintas Ternak dapat dilihat pada Gambar 5 berikut menunjukkan diagram konteks dari sistem yang dibuat. 


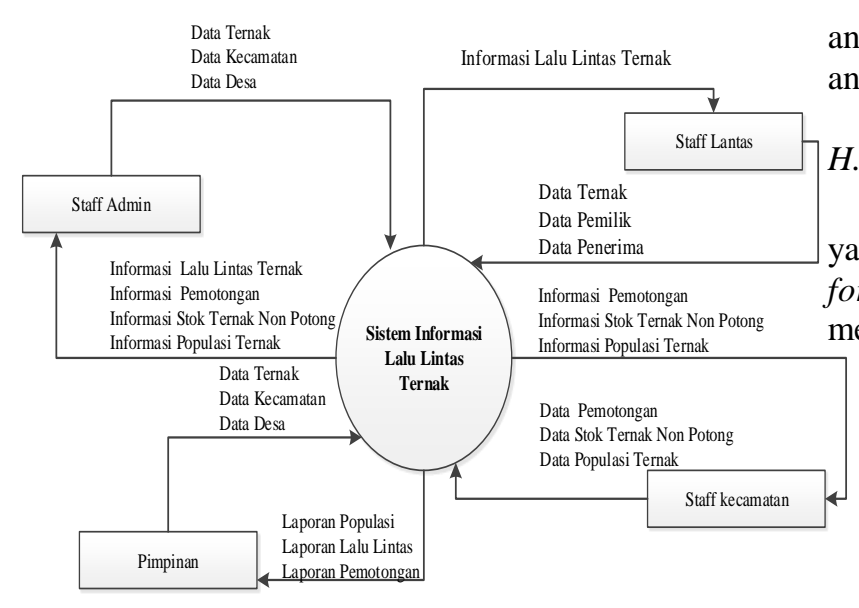

Gambar 5. Diagram konteks

\section{F. Perancangan Antarmuka Sistem}

Perancangan antarmuka (interface) dirancang sebagai Gambaran awal sistem yang akan dibangun. Perancangan antarmuka sistem meliputi beberapa pengguna diantaranya staff admin, staff kecamatan, staff lantas, pimpinan. Struktur antarmuka sistem dapat dilihat pada Gambar 6.

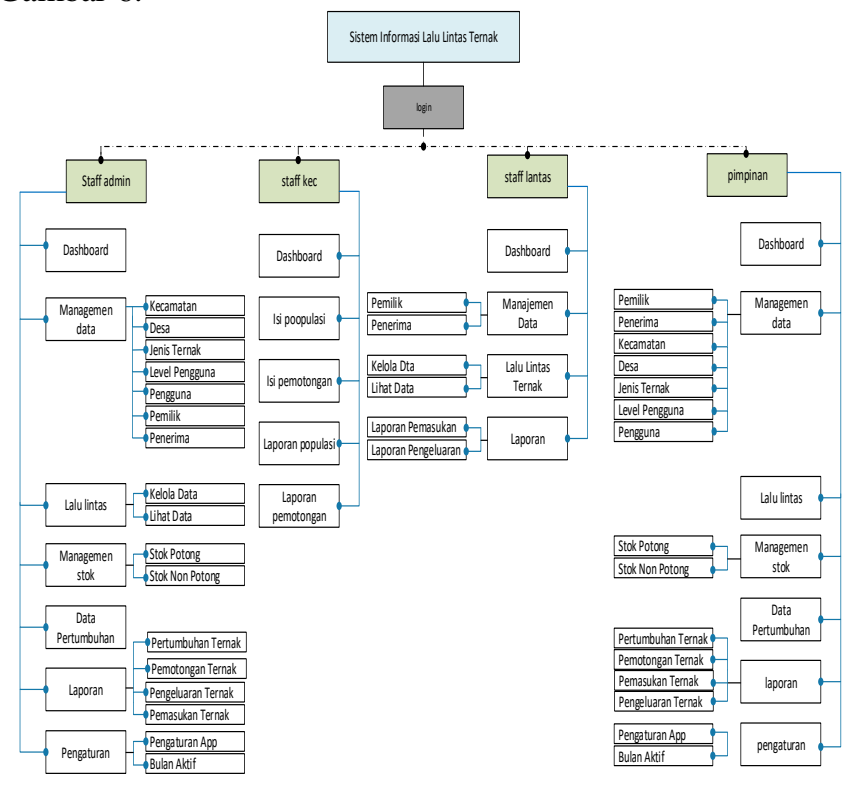

Gambar 6. Struktur antarmuka sistem

\section{HASIL IMPLEMENTASI DAN PENGUJIAN}

\section{G. Hasil Penelitian}

Perancangan yang telah dilakukan terdiri dari perancangan arsitektur sistem, diagram alir sistem, dan basis data. Perancangan tersebut menghasilkan sebuah Sistem Informasi Lalu Lintas Ternak. Antarmuka dari sistem diantaranya adalah antarmuka staff admin, antarmuka staff kecamatan, antarmuka staff lantas dan antarmuka pimpinan/kepala dinas peternakan.

\section{H. Antarmuka Halaman Login}

Antarmuka halaman login (Gambar 7) yaitu halaman yang diakses oleh pengguna. Pada halaman ini terdapat form login yang digunakan oleh pengguna ketika ingin menggunakan sistem.

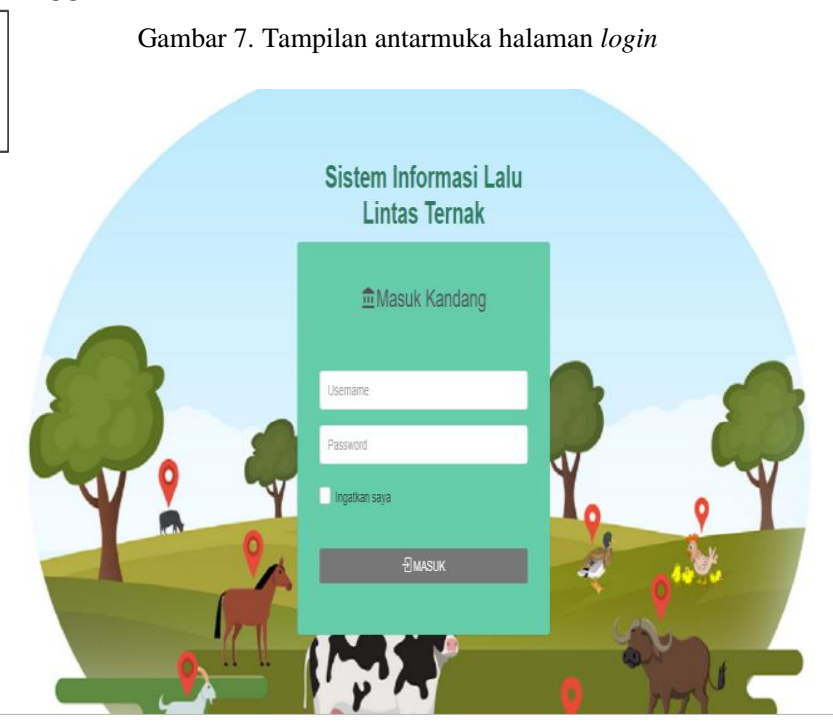

\section{Antarmuka Staff Admin}

Hasil perancangan antarmuka sistem salah satunya adalah antarmuka staff admin. Terdiri beberapamenu yaitu dashboard, manajemen data, lalu lintas ternak, manajemen stok, data populasi ternak, laporan, pengaturan.

Dashboard merupakan menu utama setelah pengguna berhasil login. Pada halaman ini ditampilkan informasi grafik populasi ternak, grafik pemotongan ternak, grafik pemasukan ternak dan grafik pengeluaran ternak. Dan terdapat juga informasi jumlah desa yang di-input-kan, jumlah kecamatan, jenis hewan dan pengguna yang telah diberi hak akses. Tampilan halaman dashboard dapat dilihat pada Gambar 8.

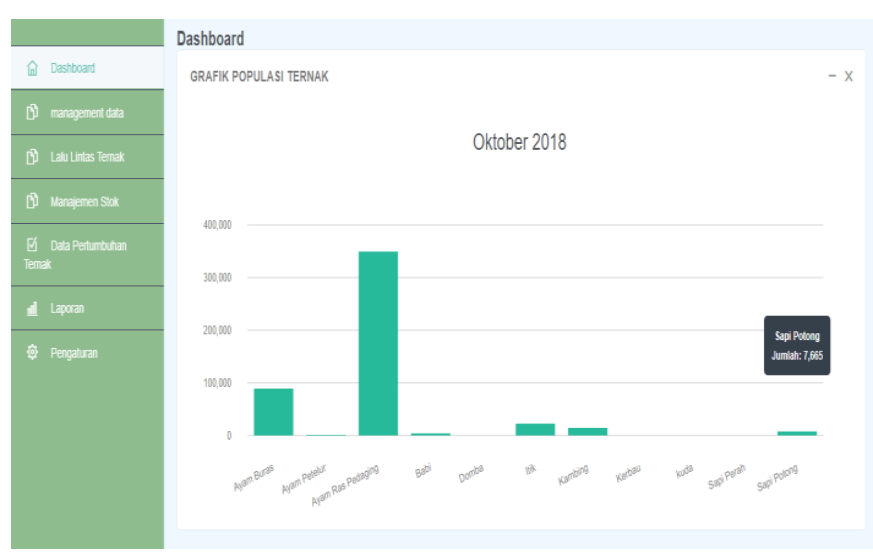

Gambar 8. Antarmuka halaman menu dashboard 


\section{J. Antarmuka Staff Kecamatan}

Hasil perancangan antar muka sistem salah satunya adalah antarmuka staff kecamatan. Terdiri beberapa 5 menu yaitu dashboard, isi populasi, isi pemotongan, laporan populasi, laporan pemotongan.

Dashboard merupakan menu utama setelah pengguna berhasil login. Pada halaman ini ditampilkan informasi grafik populasi ternak dan grafik pemotongan ternak. Dan terdapat juga informasi jumlah desa yang di-inpu-tkan, jumlah kecamatan, jenis hewan dan pengguna yang telah diberi hak akses. Tampilan halaman menu dashboard ternak dapat dilihat pada Gambar 9.

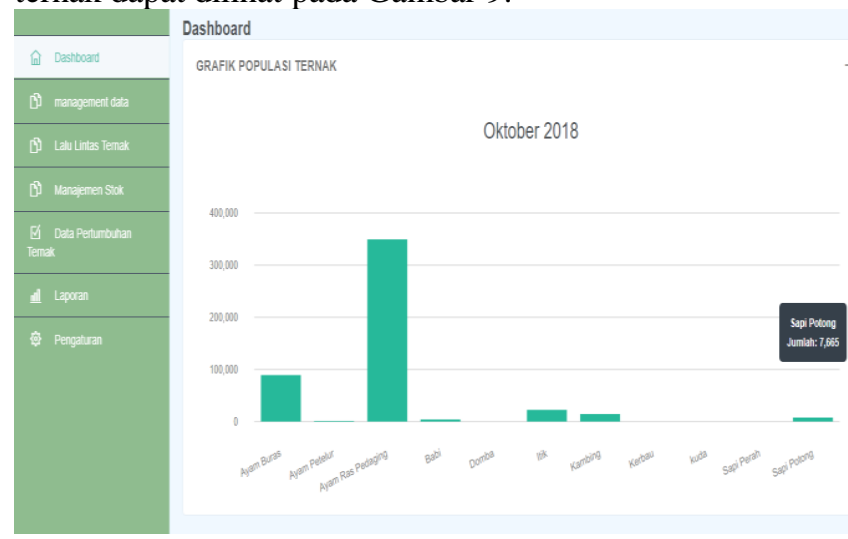

Gambar 9. Antarmuka halaman menu dashboard

\section{K. Antarmuka Staff Lantas}

Hasil perancangan antar muka sistem salah satunya adalah antarmuka staff lantas. Terdiri beberapa 4 menu yaitu dashboard, manajemen data, lalu lintas ternak, laporan.

Dashboard merupakan menu utama setelah pengguna berhasil login. Pada halaman ini ditampilkan informasi grafik pemasukan ternak dan grafik pengeluaran ternak. Dan terdapat juga informasi jumlah desa yang di-inputkan, jumlah kecamatan, jenis hewan dan pengguna yang telah diberi hak akses. Tampilan halaman menu dashboard ternak dapat dilihat pada Gambar 10.

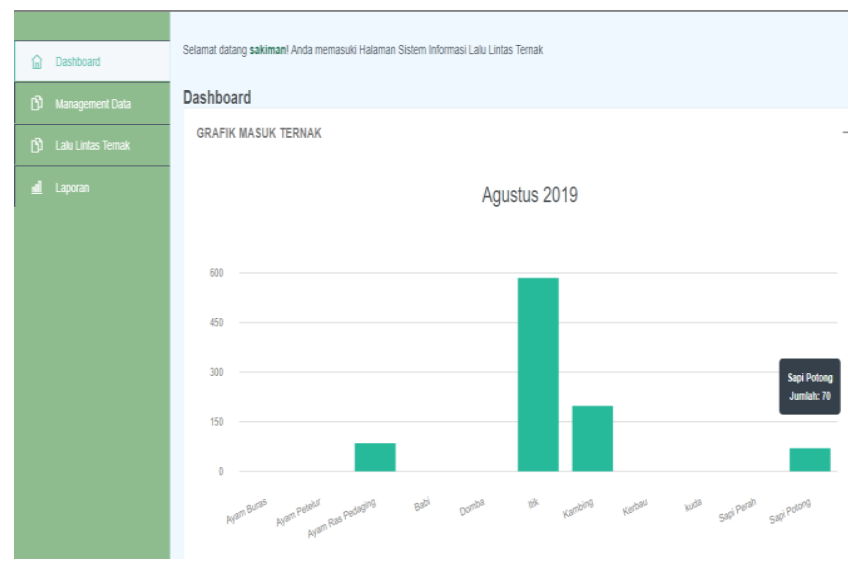

Gambar 10. Antarmuka halaman menu dashboard

\section{Antar Muka Pimpinan}

Hasil perancangan antarmuka sistem salah satunya adalah antarmuka pimpinan. Terdiri beberapa 8 menu yaitu dashboard, manajemen data, lalu lintas ternak, manajemen stok, data populasi ternak, laporan, pengaturan.

Dashboard merupakan menu utama setelah pengguna berhasil login. Pada halaman ini ditampilkan informasi grafik populasi ternak, grafik pemotongan ternak, grafik pemasukan ternak dan pengeluaran ternak. Dan terdapat juga informasi jumlah desa yang di-input-kan, jumlah kecamatan, jenis hewan dan pengguna yang telah diberi hak akses. Tampilan halaman menu dashboard dapat dilihat pada Gambar 11.

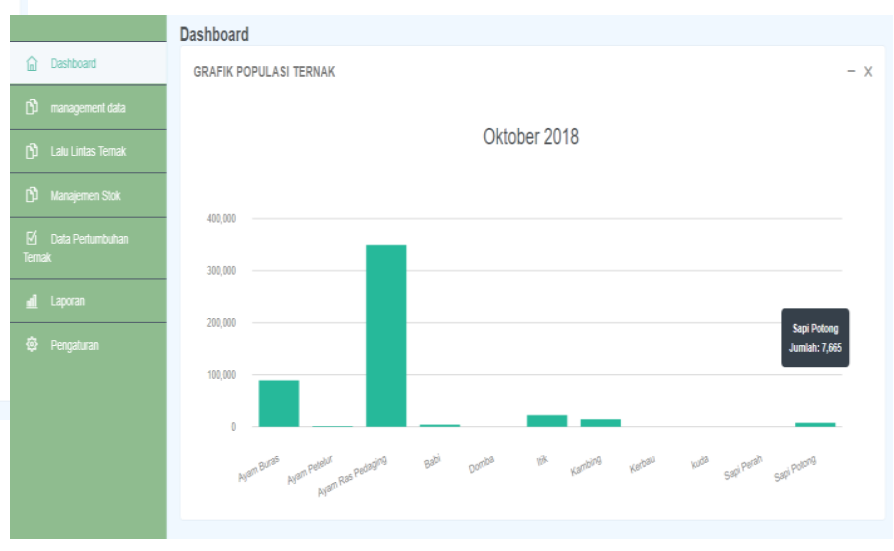

Gambar 11. Antarmuka halaman menu dashboard

\section{Pengujian}

Pada penelitian dilakukan tiga jenis pengujian yaitu pengujian black box, pengujian usability.

\section{1) Pengujian Black Box}

Black Box pada perangkat lunak dilakukan untuk menguji kesesuaian antara masukan dengan hasil yang ditampilkan pada sistem. Pengujian ini berfokus pada spesifikasi fungsional dari software, menguji kondisi input program berdasarkan apa yang dilihat, hanya fokus terhadap fungsionalitas dan output. Pengujian ini perlu dilakukan untuk melihat respon yang diberikan oleh sistem saat melakukan proses input data. Pengujian input data dilakukan pada data login, input manajement data, input data lalu lintas input data populasi ternak, input pemotongan ternak, input data pengaturan sistem, input data bulan aktif dan pencarian data ternak.

a. Pengujian Login

Pengujian input data dilakukan pada halaman login. Input data yang diuji adalah saat memasukkan username dan password. Lihat Tabel 1.

\section{TABEL I}

PENGUJIAN HASIL UJI INPUT LOGIN

\begin{tabular}{|c|l|c|l|}
\hline \multicolumn{2}{|c|}{$\begin{array}{c}\text { Skenario } \\
\text { Pengujian }\end{array}$} & \multicolumn{1}{|c|}{$\begin{array}{c}\text { Hasil } \\
\text { Uji }\end{array}$} & \multicolumn{1}{|c|}{$\begin{array}{c}\text { Hasil Yang Diharapkan } \\
\text { (Keterangan) }\end{array}$} \\
\hline 1 & $\begin{array}{l}\text { Input data } \\
\text { kosong }\end{array}$ & Tidak Berhasil & $\begin{array}{l}\text { Tidak dapat masuk ke } \\
\text { sistem dan menampilkan } \\
\text { pesan:"Please fill out this }\end{array}$ \\
\hline
\end{tabular}




\begin{tabular}{|c|l|l|l|}
\hline & & & field". \\
\hline 2 & $\begin{array}{l}\text { Input data } \\
\text { salah satu } \\
\text { kosong }\end{array}$ & Tidak Berhasil & $\begin{array}{l}\text { Tidak dapat masuk ke } \\
\text { sistem, dan menampilkan } \\
\text { pesan kesalahan: } \\
\text { "Please fill out this field" }\end{array}$ \\
\hline 3 & $\begin{array}{l}\text { Input semua } \\
\text { data diisi }\end{array}$ & Berhasil & $\begin{array}{l}\text { Berhasil Login dan Masuk } \\
\text { ke sistem }\end{array}$ \\
\hline 4 & $\begin{array}{l}\text { Inputusernam } \\
\text { e \& password } \\
\text { tidak benar }\end{array}$ & Tidak Berhasil & $\begin{array}{l}\text { Sistem akan menolak jika } \\
\text { disimpan, dan menampilkan } \\
\text { pesan kesalahan: } \\
\text { "pastikan username dan } \\
\text { password anda benar" }\end{array}$ \\
\hline 5 & $\begin{array}{l}\text { Input } \\
\text { username \& } \\
\text { password } \\
\text { sebagai } \text { staff } \\
\text { admin }\end{array}$ \\
\hline 6 & $\begin{array}{l}\text { Input } \\
\text { username \& } \\
\text { password } \\
\text { sebagai } \text { staff } \\
\text { kecamatan }\end{array}$ & Berhasil login dan masuk ke \\
\hline 7 & $\begin{array}{l}\text { Input } \\
\text { username \& } \\
\text { password } \\
\text { sebagai } \\
\text { pimpinan }\end{array}$ & Berhasil & $\begin{array}{l}\text { Berhasil login dan masuk ke } \\
\text { sistem }\end{array}$ \\
\hline
\end{tabular}

b. Pengujian manajemen data

Pengujian input data dilakukan pada halaman administrator oleh staff admin. Input data yang diuji adalah saat memasukkan data kecamatan, desa, pengguna, pemilik dan penerima. Proses pengujian data lainnya juga dilakukan sama dan menghasilkan perilaku sistem yang juga sama. Lihat Tabel 2.

TABEL II

PENGUJIAN HASIL UJI INPUT DATA PADA PROSES MANAJEMEN DATA

\begin{tabular}{|c|l|l|l|}
\hline \multicolumn{2}{|c|}{$\begin{array}{c}\text { Skenario } \\
\text { Pengujian }\end{array}$} & \multicolumn{1}{|c|}{$\begin{array}{c}\text { Hasil } \\
\text { Uji }\end{array}$} & \multicolumn{1}{c|}{$\begin{array}{c}\text { Hasil Yang Diharapkan } \\
\text { (Keterangan) }\end{array}$} \\
\hline 1 & $\begin{array}{l}\text { Input data } \\
\text { kosong }\end{array}$ & $\begin{array}{l}\text { Tidak } \\
\text { Berhasil }\end{array}$ & $\begin{array}{l}\text { Sistem akan menolak jika } \\
\text { disimpan, dan menampilkan pesan } \\
\text { kesalahan: } \\
\text { "This value is required" }\end{array}$ \\
\hline 2 & $\begin{array}{l}\text { Input data } \\
\text { salah satu } \\
\text { kosong }\end{array}$ & $\begin{array}{l}\text { Tidak } \\
\text { Berhasil }\end{array}$ & $\begin{array}{l}\text { Tidak berhasil menyimpan dan dan } \\
\text { menampilkan pesan } \\
\text { kesalahan:" This value is required" }\end{array}$ \\
\hline 3 & $\begin{array}{l}\text { Input } \\
\text { semua data } \\
\text { diisi }\end{array}$ & Berhasil & $\begin{array}{l}\text { Sistem akan menyimpan data dan } \\
\text { menampilkan pada tabel. }\end{array}$ \\
\hline
\end{tabular}

c. Pengujian Lalu Lintas Ternak

Pengujian input data lalu lintas ternak pada halaman administrator oleh staff admin. Input data yang diuji adalah saat memasukkan data status lintas, kategori ternak, jumlah, umur, kondisi, pemilik, penerima, bulan input, petugas kesehatan yang bertanggung jawab. Proses pengujian data lainnya juga dilakukan sama dan menghasilkan perilaku sistem yang juga sama Lihat Tabel.3
TABEL III

PENGUJIAN HASIL UJI INPUT DATA LALU LINTAS TERNAK

\begin{tabular}{|c|l|l|l|}
\hline \multicolumn{2}{|c|}{$\begin{array}{c}\text { Skenario } \\
\text { Pengujian }\end{array}$} & \multicolumn{1}{|c|}{$\begin{array}{c}\text { Hasil } \\
\text { Uji }\end{array}$} & \multicolumn{1}{c|}{$\begin{array}{c}\text { Hasil Yang Diharapkan } \\
\text { (Keterangan) }\end{array}$} \\
\hline 1 & $\begin{array}{l}\text { Input data } \\
\text { kosong }\end{array}$ & $\begin{array}{l}\text { Tidak } \\
\text { Berhasil }\end{array}$ & $\begin{array}{l}\text { Sistem akan menolak jika } \\
\text { disimpan, dan menampilkan } \\
\text { pesan kesalahan: } \\
\text { "This value is required" }\end{array}$ \\
\hline 2 & $\begin{array}{l}\text { Input data } \\
\text { salah satu } \\
\text { kosong }\end{array}$ & $\begin{array}{l}\text { Tidak } \\
\text { Berhasil }\end{array}$ & $\begin{array}{l}\text { Sistem akan menolak jika } \\
\text { disimpan, dan menampilkan } \\
\text { pesan kesalahan: } \\
\text { "This value is required" }\end{array}$ \\
\hline 3 & $\begin{array}{l}\text { Input } \\
\text { semua } \\
\text { data diisi }\end{array}$ & Berhasil & $\begin{array}{l}\text { Sistem akan menyimpan data } \\
\text { dan menampilkan pada tabel. }\end{array}$ \\
\hline
\end{tabular}

\section{d. Pengujian Pengaturan}

Pengujian input data pengaturan dilakukan pada halaman administrator oleh staff admin. Input data yang diuji adalah saat memasukkan data nama sistem, $u r l, w e b$ title, alamat, telp dan pejabat yang bertanda tangan dan input bulan. Proses pengujian data lainnya juga dilakukan sama dan menghasilkan perilaku sistem yang juga sama. Lihat Tabel 4.

TABEL IV

PENGUJIAN HASIL UJI INPUT PENGATURAN

\begin{tabular}{|c|l|l|l|}
\hline \multicolumn{2}{|c|}{$\begin{array}{c}\text { Skenario } \\
\text { Pengujian }\end{array}$} & \multicolumn{1}{|c|}{$\begin{array}{c}\text { Hasil } \\
\text { Uji }\end{array}$} & $\begin{array}{c}\text { Hasil Yang Diharapkan } \\
\text { (Keterangan) }\end{array}$ \\
\hline 1 & $\begin{array}{l}\text { Input data } \\
\text { kosong }\end{array}$ & $\begin{array}{l}\text { Tidak } \\
\text { Berhasil }\end{array}$ & $\begin{array}{l}\text { Sistem akan menolak jika } \\
\text { disimpan, dan menampilkan } \\
\text { pesan kesalahan: } \\
\text { "This value is required" }\end{array}$ \\
\hline 2 & $\begin{array}{l}\text { Input data } \\
\text { salah satu } \\
\text { kosong }\end{array}$ & Berhasil & $\begin{array}{l}\text { Sistem akan menolak jika } \\
\text { disimpan, dan menampilkan } \\
\text { pesan kesalahan: } \\
\text { "This value is required" }\end{array}$ \\
\hline 2 & $\begin{array}{l}\text { Input data } \\
\text { diisi }\end{array}$ & Berhasil & Sistem akan menyimpan data . \\
\hline
\end{tabular}

e. Pengujian Data Populasi Ternak

Pengujian input data populasi ternak dilakukan pada halaman sistem informasi lalu lintas ternak oleh staff kecamatan. Input data yang diuji adalah saat memasukkan data populasi tiap desa dan kecamatan. Proses pengujian data lainnya juga dilakukan sama dan menghasilkan perilaku sistem yang juga sama. Lihat Tabel 5 . 
TABEL V

PENGUJIAN HASIL UJI INPUT DATA POPULASI TERNAK

\begin{tabular}{|c|l|l|l|}
\hline \multicolumn{2}{|c|}{$\begin{array}{c}\text { Skenario } \\
\text { Pengujian }\end{array}$} & \multicolumn{1}{|c|}{$\begin{array}{c}\text { Hasil } \\
\text { Uji }\end{array}$} & \multicolumn{1}{|c|}{$\begin{array}{c}\text { Hasil Yang Diharapkan } \\
\text { (Keterangan) }\end{array}$} \\
\hline 1 & $\begin{array}{l}\text { Input data } \\
\text { kosong }\end{array}$ & $\begin{array}{l}\text { Tidak } \\
\text { Berhasil }\end{array}$ & $\begin{array}{l}\text { Sistem akan menolak jika } \\
\text { disimpan, dan menampilkan pesan } \\
\text { kesalahan: } \\
\text { "This value is required" }\end{array}$ \\
\hline 2 & $\begin{array}{l}\text { Input } \\
\text { semua } \\
\text { data diisi }\end{array}$ & Berhasil & $\begin{array}{l}\text { Sistem akan menyimpan data dan } \\
\text { menampilkan data pada tabel. }\end{array}$ \\
\hline
\end{tabular}

f. Pengujian Data Pemotongan Ternak

Pengujian input data pemotongan ternak dilakukan pada halaman sistem informasi lalu lintas ternak oleh staff kecamatan. Input data yang diuji adalah saat memasukkan data pemotongan ternak tiap desa dan kecamatan. Proses pengujian data lainnya juga dilakukan sama dan menghasilkan perilaku sistem yang juga sama. Lihat Tabel 6.

TABEL VI

PENGUJIAN PENCARIAN DATA PEMOTONGAN

\begin{tabular}{|c|l|l|l|}
\hline \multicolumn{2}{|c|}{$\begin{array}{l}\text { Skenario } \\
\text { Pengujian }\end{array}$} & \multicolumn{1}{|c|}{$\begin{array}{c}\text { Hasil } \\
\text { Uji }\end{array}$} & Hasil Yang Diharapkan \\
\hline 1 & $\begin{array}{l}\text { Input data } \\
\text { kosong }\end{array}$ & $\begin{array}{l}\text { Tidak } \\
\text { Berhasil }\end{array}$ & $\begin{array}{l}\text { Sistem akan menolak jika } \\
\text { disimpan, dan menampilkan } \\
\text { pesan kesalahan: } \\
\text { "This value is required" }\end{array}$ \\
\hline 2 & $\begin{array}{l}\text { Input } \\
\text { semua } \\
\text { data diisi }\end{array}$ & Berhasil & $\begin{array}{l}\text { Sistem akan menyimpan data dan } \\
\text { menampilkan data pada tabel. }\end{array}$ \\
\hline
\end{tabular}

\section{2) Hasil Pengujian Aspek Usability}

Pengujian usability dilakukan dengan mengajukan aspek pertanyaan kepada responden. Pengujian ini dilakukan untuk menguji sejauh mana pengguna dapat menggunakan sistem ini. Jumlah responden pada penelitian ini adalah 3 orang yang terdiri dari Staff lantas, Staff kecamatan dan pimpinan/kepala Dinas Pertanian dan Peternakan Kayong Utara. Hasil pengujian ini dihitung dengan skala likert. Hasil perhitungan dapat dilihat pada tabel 7 dengan perhitungan sebagai berikut :

TABEL VII

HASIL PENGUJIAN ASPEK USABILITY

\begin{tabular}{|c|c|c|c|c|c|c|}
\hline \multirow{2}{*}{ Aspek } & \multicolumn{5}{|c|}{ Hasil Pengujian } & $\begin{array}{c}\text { Persentase } \\
\text { Likert } \\
(\%)\end{array}$ \\
\cline { 2 - 6 } & STB & TB & CB & B & SB & 86,7 \\
\hline 1. & 0 & 0 & 0 & 2 & 1 & 80 \\
\hline 2. & 0 & 0 & 0 & 3 & 0 & 80 \\
\hline 3. & 0 & 0 & 1 & 1 & 1 & 86,7 \\
\hline 4. & 0 & 0 & 0 & 2 & 1 & 86,7 \\
\hline 5. & 0 & 0 & 0 & 2 & 1 & 73,4 \\
\hline 6. & 0 & 0 & 1 & 2 & 0 & 100 \\
\hline 7. & 0 & 0 & 0 & 0 & 3 & 73,4 \\
\hline 8. & 0 & 0 & 1 & 2 & 0 & \\
\hline
\end{tabular}

Berdasarkan hasil pengujian usability oleh 3 responden dari 8 pertanyaan, 6 diantaranya memiliki nilai diatas $80 \%$ dan hanya 2 pertanyaan yang memberikan presentase penilaian di bawah $80 \%$. Sehingga disimpulkan sistem dapat diterima dan digunakan oleh Staff Dinas Pertanian dan Peternakan Kayong Utara.

\section{KESIMPULAN}

\section{N. Kesimpulan}

Berdasarkan dari hasil analisis dan pengujian Sistem Informasi Lalu Lintas Ternak pada Dinas Pertanian Dan Peternakan Kayong Utara, maka didapat kesimpulan yang ada adalah sebagai berikut:

Hasil dari pengujian blackbox, sistem berhasil beroperasi dengan baik dan hasil dari pengujian usability dengan 3 oleh 3 responden dari 8 pertanyaan, 6 diantaranya memiliki nilai diatas $80 \%$ dan hanya 2 pertanyaan yang memberikan presentase penilaian di bawah $80 \%$ maka disimpulkan sistem dapat diterima dan digunakan oleh Staff Dinas Pertanian dan Peternakan Kayong Utara.

Sistem Informasi Lalu Lintas Ternak berhasil dibangun dan dapat membantu kepala bidang peternakan dan kesehatan hewan dalam membuat kebijakan, evaluasi dan administrasi peternakan dan kesehatan hewan. Kepala bidang peternakan dan kesehatan hewan memiliki tugas dan fungsi melakukan kontrol dan koordinasi terhadap lalu lintas ternak, meliputi jumlah dan kondisi hewan ternak pada Dinas Pertanian dan Peternakan Kayong Utara.

Sehingga sistem yang di bangun mampu menggantikan proses pendataan yang konvensional dimana pada sistem ini, setiap data yang di-input oleh staff akan terekap langsung pada data laporan untuk KaBid sehingga tidak perlu ng-input-kan data berulang dan dapat mencegah terlambatnya pendistribusian laporan.

Adapun hal yang dapat menjadi saran sebagai bahan pertimbangan dan masukan untuk pengembangan yaitu membangun sistem informasi lalu lintas ternak yang dapat menangani bisnis proses dari lalu lintas ternak secara keseluruhan mulai dari kemungkinan yang dapat terjadi saat proses lalu lintas ternak berlangsung.

\section{REFERENSI}

[1] V. C. Hamacher, Z. G. Vranesic, and S. G. Zaky, Computer Organization, 5th ed., vol. VII, no. V. New York: McGraw-Hill New York et al., 2002.

[2] H. H. Hamid, Peraturan Bupati Kayong Utara Tentang Pengaturan Lalu Lintas Ternak dan atau Bahan Asal Ternak. Sukadana: Bupati Kayong Utara, 2018.

[3] A. I. Maulana and L. Fitriani, "Rancang Bangun Sistem Informasi Pengolahan Data Ternak di Perusahaan Dagang Perusahaan Pengengembangan Usaha Ternak Indonesia (PD. PPUTI), J. Algoritm., vol. 13, no. 1, 2016.

[4] S. Natarsyah and T. Taufiq, "Perancangan Sistem Informasi Pendataan Ternak Menggunakan PHP dan MySql,” JUTISI, vol. 5, no. 2, 2017.

[5] J. Weriza, "Sistem Informasi Berbasweb pada Dinas Peternakan dan Perikanan Kabupaten Tanah Datar," Komput. Teknol. Inf., vol. 3, no. 2, 2017. 
[6] J. Hartono, Analisis dan Desain Sistem Informasi: Pendekatan Terstruktur Teori dan Praktek Aplikasi Bisnis. Yogyakarta: Penerbit Andi, 2005.

[7] S. Azhar, "Sistem Informasi Manajemen: Konsep dan Pengembangannya," Ed. ketiga,(Bandung Lingga Jaya, 2004), 2004.

[8] B. D. Gordon, "Kerangka Dasar Sistem Informasi Manajemen," PPM, Jakarta, 2002.

[9] G. H. Bodnar and W. S. Hopwood, "Sistem Informasi Akuntansi," Jakarta: Salemba Empat, 2006.

[10] J. A. O’Brein, "Pengantar Sistem Informasi. Edisi Keduabelas. Diterjemahkan oleh Dewi Fitriasari dan Deny Amos Kwary." McGraw-Hill Irwin. Dan PT. Salemba Empat, Jakarta, 2005.

[11] E. Arbie, Pengantar Sistem Informasi Manajemen, vol. 1. Jakarta: Bina Alumni Indonesia, 2000.

[12] K. E. Kendall and J. E. Kendall, Analisa dan Perancangan Sistem, 5th ed. Jakarta: PT Indeks, 2003.

[13] R. S. Pressman, Software Engineering: a Practitioner's Approach. Britania Raya: Palgrave Macmillan, 2005.

[14] R. S. Pressman, Rekayasa Perangkat Lunak Pendekatan Praktisi (Buku Satu). Yogyakarta: Penerbit Andi, 2002.

[15] Z. Ahkamiyati, "Pengembangan dan Analisis Kualitas Sistem Informasi Bimbingan Tugas Akhir Skripsi Online untuk Mahasiswa Tingkat Akhir Pendidikan Teknik Elektronika Ft Uny,” Lumbung Pustaka UNY, vol. 147, pp. 11-40, 2016.

[16] J. Rubin and D. Chisnell, Handbook Of Usability Testing: How To Plan, Design and Conduct Effective Tests. New Jersey: John Wiley \& Sons, 2008.

[17] P. D. Sugiyono, Metode Pnelitian Kuantitatif dan Kualitatif dan R\&D. Bandung: Alfabeta, 2008.

[18] M. Shalahuddin and A. S. Rosa, Rekayasa Perangkat Lunak Terstruktur dan Berorientasi Objek. Bandung: Informatika, 2013. 